\title{
Writing an "Intangible" Text: Between Politics, Science and Bearers
}

\author{
MIRELA HROVATIN \\ Republic of Croatia Ministry of Culture, Zagreb
}

\begin{abstract}
In this paper I will explain some of the processes behind the making of the lists of the so called "intangible cultural heritage" (ICH), both on the national (the Registry of Cultural Goods of the Republic of Croatia) and the international level (UNESCO's ICH lists). The analysis is based on the situations that led to the inscriptions into which I have some insight as an insider, as well as on the texts about ICH elements written for the needs of inscription in which some of the issues of ICH policy are reflected. Touching upon some of the issues that I had to face as an ethnologist/ cultural anthropologist working on the inscription of ICH elements into the Registry and nominations for inscriptions on the UNESCO's lists, I will try to explain the complexity of the position of an expert in a state body trying to reconcile the demands of politics, science and the "bearers" of the listed heritage.
\end{abstract}

Key words: intangible cultural heritage, UNESCO, Registry of Cultural Goods of the Republic of Croatia

\section{INTRODUCTION}

This paper presents reflections on the initial and on-going efforts to inscribe the so called "intangible cultural heritage" (ICH) on UNESCO's lists and on the national list (the Registry of Cultural Goods of the Republic of Croatia) on the basis of the analysis of texts about ICH elements from the archive of the Croatian Ministry of Culture and my insight into and participation in those processes as the official in the Ministry. Analyzing several cases, I will explain various situations that led to the inscriptions, showing the complexity of the issue of ICH listing. Some of the terminology used in this work will correspond to the terminology used by UNESCO and the international expert community involved in the implementation of UNESCO's policy on the so called "intangible cultural heritage" (ICH), such as ICH element, bearers, safeguarding, measures, lists, etc., for which all the basic definitions are available elsewhere. ${ }^{1}$

\footnotetext{
${ }^{1}$ For more on definitions of ICH see UNESCO's 2003 Convention for the Safeguarding of Intangible Cultural Heritage and the Croatian 1999 Act on the Protection and Preservation of Cultural Goods, as well as reflections on the definitions in the literature cited in this paper.
} 


\section{THE BEGINNING OF WRITING TEXTS ABOUT ICH}

One of the first activities related to ICH safeguarding in Croatia on the administrative level in the Ministry of Culture, besides sending information concerning ICH in Croatia to UNESCO during the 1990s and the introduction of the category of ICH in the 1999 Act on the Protection and Preservation of Cultural Goods, was the decision ${ }^{2}$ of the Ministry taken in 2001 to involve external ${ }^{3}$ experts (who later became members of the advisory body) to nominate Istrian traditional music for the second cycle of UNESCO's program of Proclamation of the Masterpieces of Oral and Intangible Heritage of Humanity in $2003 .{ }^{4}$ For this purpose a special UNESCO form ${ }^{5}$ had to be filled in, and the first text about an ICH element in Croatia was written in 2002 as a candidature/nomination file. It was done by Mario Marušić, an expert who is also "the bearer of the element". Despite the fact that the text covered basically all parts of the Masterpieces form, which can be seen from its analysis, for some reason it did not meet UNESCO's criteria. After analyzing the background on the basis of the available archival documents and the context in which the candidature took place, it is clear that it was other reasons, rather than an inadequate ${ }^{6}$ textual description of the element, that influenced UNESCO's decision, as is evidenced from the review of the application that the Ministry commissioned from external experts after receiving UNESCO's reply.

UNESCO's initial reply to the first file was aimed at "asking if the candidature should be constructed as multinational" (Nikočević 2004: 2). Although some of the other analyses refer to other aspect of the background of this

\footnotetext{
${ }^{2}$ The decision to send the proposition from Croatia for the UNESCO's program of the Proclamation of the Masterpieces was influenced by the invitation from UNESCO to start making ICH lists (c.f. Guide for the Candidature Files for Masterpieces) and by the fact that the first proclamation of masterpieces took place in 2001 and that Croatia did not send a proposition at that time. The Ministry sent the invitation to all of its conservation departments in 2001 to submit propositions from the territory they cover (there are 19 conservation departments, the office in the City of Zagreb is not under the Ministry but covers the area of Zagreb). Out of those propositions, Istrian music was chosen as the candidate. The file mentions some experts on tangible heritage who also contributed to the choice of this element. Based on the Internal report on the activities of the Division for ICH, 2001: 1-3.

3 "External experts" refers to experts from institutions other than the Ministry of Culture (ethnologists from the Institute of Ethnology and Folklore Research, Department for Ethnology and Cultural Anthropology at the University of Zagreb, museums, etc.). Some of the experts will be kept anonymous, such as the authors of reviews, etc.

${ }^{4}$ The program of the Masterpieces was actually one of several preparatory activities that would ensure the implementation of a part of the 2003 Convention, they "were considered a short-term goal that would serve [...] the shaping of the Convention as a normative instrument" (Zebec 2013: 317); see also Overview on the Proclamation of Masterpieces (http).

${ }^{5}$ Not to go into the origin of the creation of UNESCO's nomination forms or Croatian forms for lists of tangible or intangible cultural heritage, I compared the versions of forms that were most appropriate for this analysis, taking into consideration the changes that influenced the writing of the texts about ICH in Croatia.

${ }^{6}$ The review on the Istrian Ethnomusical Microcosmos, 2001, archive, Ministry of Culture.
} 
nomination such as "UNESCO working in the direction of precisely defined national categories" (cf. Ceribašić 2013: 303), it might be added that in the text of the nomination it is clear that UNESCO's insistence on clarifying who the people involved in the tradition were and where the tradition occurred was caused by the definition of the community ${ }^{7}$ which the file refers to was not as precise as UNESCO wanted or could understand from its "outsider" position:

Istria is the largest peninsula on the Eastern coast of the Adriatic sea [...] The largest part of Istria is in Croatia, a smaller part in Slovenia and the city of Muggia with its surroundings is situated in Italy. [...] some musical styles of certain traditions are part of heritage of different ethnic groups $[\ldots] .^{8}$

For UNESCO evaluators who read the text for the first time, it might have seemed that different countries with their ethnic groups are the bearers, and not that Istria within the borders of Croatia is the space of this musical tradition and that different ethnic groups live there. The text was amended in part based on the reviews mentioned above; however the second answer from UNESCO again asked for a revision of the file, which proves that there was no intention from UNESCO to inscribe the element at that time. The second answer mostly refers to the lack of involvement of the communities concerned in the making of the file and to the action plan that should put less emphasis on research. ${ }^{9}$ This also proves that the criteria for the Masterpieces' list when compared to the criteria for the World Heritage List, ${ }^{10}$ although very similar, paid more attention to the bearers of the ICH element as, from the point of view of UNESCO, they were the ones who "own"11 their heritage.

\footnotetext{
${ }^{7}$ The community in the context of UNESCO ICH policy stands for all the people who still practice their tradition, have the knowledge and skills, so called "know-how" as well as all the people of an area who identify with the tradition defined as an ICH element. For more on how UNESCO defines communities: http://www.unesco.org/culture/ich/doc/src/00034-EN.pdf.

${ }^{8}$ The candidature file on Istrian music, 2002, paragraph 2.a. All translations of archival documents in Croatian are mine.

${ }^{9}$ Official correspondence between the Ministry and UNESCO - UNESCO's official letter to the Ministry from 2004: 1.

${ }^{10}$ When comparing the UNESCO's criteria and forms for the World Heritage List and for Intangible Heritage Lists (including Masterpieces), it is obvious that the outline for the description of cultural elements and other basic information needed for inscription is very similar, in moments the same. Only later, the form for the ICH became more focused on other aspects of the element such as participation of bearers, visibility of ICH in general, intercultural dialogue, etc.

${ }^{11}$ The idea that the people in a certain area own a tradition and the right to perform it, use or present it, is both the attitude of the bearers themselves towards their heritage (what I have seen also from my personal correspondence with them) and the "newer" rules (laws) of owning intellectual rights to an idea, although not applicable entirely to culture (tradition) as such as it belongs to everybody. UNESCO avoids the use of the term "own" and instead mostly uses the term "their" tradition/ICH to refer to the people who practice certain traditions which can be seen in most of the official UNESCO published texts (e.g. http://www.unesco.org/culture/ich/doc/src/00034-EN.pdf).
} 
What UNESCO knew long before ${ }^{12}$ the inscriptions into an international list was that it was inevitable that the rights to the heritage of the community/ communities involved in it would be confirmed; and by mentioning the exact bearers UNESCO considered that they would be protected from others who might be interested in using "their" heritage, as was already stated in the documents that preceded the 2003 Convention:

Protection of folklore: In so far as folklore constitutes manifestations of intellectual creativity whether it be individual or collective, it deserves to be protected in a manner inspired by the protection provided for intellectual productions. $^{13}$

This is also why the Masterpieces' form introduced 'the agreement of the community or individuals concerned". ${ }^{14}$

Actually, most of the first proposals for inscription on the list(s), as well as later proposals, were, in addition to several other reasons, almost always additionally motivated by the communities' need for protection of the right to their heritage, to its performance, name and presentation. This is, for example, visible in the elements connected to food, for which the communities wanted to secure the right to presentation and to placing their products on the market. Once that we agreed in the Ministry to direct them to the Ministry of Agriculture that could give them the protection on the market they wanted, there were fewer and fewer such proposals for inscription. The communities even used the document by which an element was inscribed in the Registry as proof of their tradition and used it as documentation to gain the protection of geographic indication from the Ministry of Agriculture several years later (for example the preparation of the slavonski kulen sausage). The need to affirm their rights using the inscription was articulated in many of the texts which the communities sent to the Ministry, e.g.:

After the attempt of the "Lado" Ensemble from Zagreb [...] to turn [moreška $]^{15}$ into a plain folklore stage performance, which could then be performed by any folklore ensemble anywhere [we] conducted a study for the protection of Korčulan moreška [...] as a unique and recognizable sword battle play. ${ }^{16}$

\footnotetext{
12 See making of the 2003 Convention on http://www.unesco.org/culture/ich/index.php?lg= en\&pg=00308.

${ }^{13}$ Recommendation on the Safeguarding of Traditional Culture and Folklore, 1989, paragraph E.(g) and F.

${ }^{14}$ Guide for the Candidature Files for Masterpieces 2001, Annex VI, Masterpieces form, paragraph 6.(d).

${ }^{15}$ Moreška is a type of the sword dance/drama which has been performed in Korčula, an island in southern Croatia for centuries.

16 "Study for the Protection of Korčulan Moreška", 2003, foreword.
} 
The bearers who send or support the proposal for inscription regularly consider themselves as the only ones who can "use" their heritage, although it is our practice in the Division to inform them that they cannot be the only ones mentioned in the official version of the text. Since the bearers have the right to react to the inscription, this caused several complaints by the bearers to us in the Division that they should be mentioned somewhere in the text as the initiators of the inscription or the main bearers of the element. I had to face and resolve these reactions from the bearers, and so did my colleagues working on the inscriptions both inside the Ministry and outside it. The initiators understand the attitude of the experts about the inclusion of all the bearers, but still do not want the text to be as "neutral" as it is. However, most of the texts actually do emphasise those proposing the inscription by referring to them not as the "initiators" but as the "most active" or "willing" to safeguard their heritage. On the other hand, other bearers who received the document or even those who did not receive it officially (sometimes it is not physically possible to send it to each person individually) but who knew that "their" element had been inscribed, would be surprised to see it inscribed and usually would call us to ask what their role would be after the inscription. Usually my colleagues from the Division and I tell them to think about how they can transmit some aspects of their heritage to younger generations, give them examples of some activities done by others, depending on the type of ICH the element belongs to, advise them to make contact with the relevant experts and see if they can "help" them in some way and we also tell them that they are, in addition to the bearers mentioned in the text, the ones who can benefit from the inscription (that they can apply for funds, create various programmes, etc.). This process of notifying and involvement of as many "stakeholders" of an ICH element as possible is a way to make them aware that their heritage is "manageable" by them, instead of them, as it happens in many cases, waiting for the state, institutions or experts to come and provide "solutions" to various issues connected with their heritage. However, it does not necessarily "teach" them how to do what they choose to do, rather, it involves only those aspects of ICH that are "saveable", operational (traditional crafts and various handicrafts, music, dance, some customs) especially having in mind that the context of it has already changed and with the "planned" safeguarding measures it would change even more. In my opinion, there are already many changes taking place with or without the inscriptions into the lists, and the lists only reflect what is already under way, including managing parts of culture and using it for various purposes. Although the Ministry has had a longstanding system of monitoring the status of tangible heritage, the monitoring of ICH was influenced by UNESCO's requirement that each inscribed element and safeguarding measures 
should be monitored to make sure that it is preserved for the future. ${ }^{17}$ Most inscribed elements are analysed by experts who regularly conduct their research, so the Ministry has to ask for their evaluation when it is needed for reports, unless it can conduct research within the scope of its regular duties (less complex elements can be analysed by the experts from the Ministry). These texts that analyse the status of an element every several years are also important documents and might serve to explain what changes are happening to specific elements in time and reasons why they happen. ${ }^{18}$ I would say that it depends on each individual case whether the inscription has a positive or a negative effect on the heritage in general, but it certainly changes the bearers' perspective on their heritage to some extent, which should be more thoroughly researched in the future to be able to provide more precise answers. Recently, the experts from the Committee and the Ministry decided that the elements that can no longer be safeguarded, mainly when further transmission to younger generations is not taking place or is not likely to happen in the near future, would not inscribed into the Registry, and in such cases the bearers are advised to start thinking about managing their own heritage and to later resubmit their proposal for inscription, which is one of the ways of influencing the bearers' attitudes.

It might be said that the action plan for Istrian music that was criticized by UNESCO in 2002 still followed the approach to the element influenced by the forms for the World Heritage List. For the protected tangible heritage the plan for safeguarding is always more concrete and predictive and it involves expert engagement, but applying it for the listed ICH elements might lead to certain dilemmas: if there is control of a cultural expression, whether it is going to have an effect on the very meaning of this practice which it had for the people whose heritage it is because "all interventions into heritage [...] change the relation of people towards what they do" (Kirshenblatt-Gimblett 2013: 87), how can the bearers manage their own heritage and what would the effects be and whether all this is going to influence the possible changes that would take place without this sort of "management" of the cultural element (for example the effect some of the inscriptions had in communities that say "we have no use for it"; Nikočević 2012: 65)? By tracing the activities on some projects of safeguarding of the inscribed ICH elements in the Ministry, I have seen that certain heritage definitely might be "managed" (e.g.

${ }^{17}$ While for the Masterpieces, an action plan had to be made (Decisions from 155th Session, 1998, paragraph 6. B), today it is important that the bearers are the most important subjects of future safeguarding measures to ensure the viability of the ICH in question, so their ideas are also put in the text.

${ }^{18}$ Periodic reports on the inscribed elements are submitted using a form has been drafted by a working group consisting of the members of the Committee and representatives from the Ministry. Currently, the form is being transformed into a special questionnaire in order to provide a tool for the experts in the conservation departments to evaluate the elements. 
crafts, various lacemaking, music and dance), but that some of the heritage cannot be "controlled" in this way; therefore some of the overall heritage cannot even be classified and inscribed, it exists as it is and because "change is inherent part of culture" (Kirshenblatt-Gimblett 2013: 87), it takes on a new life over and over again under various circumstances (e.g. various social customs). Many bearers are aware of it too, but still strive to keep some aspects of their culture, the arbitrary choices so typical for (re)creating culture everywhere. Listing parts of culture in my opinion can make changes and save some aspects of it, but in general they would remain dynamic or "disappear" as it has always been.

The agreement and participation of the bearers in the preparation of candidatures and their involvement in the planning and implementation of safeguarding measures since 2008 has become one of the most important criteria for inscription on UNESCO's lists. Therefore, while working on the preparation of the nomination files in 2008 for the inscription in 2009 I pointed out the need for a clearer description in this part of the file, both to my superiors and to the external experts, which they agreed to. To understand what has to be written (not only for this particular part of the file, but for the other parts as well), I analysed the texts of the elements already inscribed on UNESCO's Representative List (see note 27), and applied the same for the Croatian nominations prepared in 2008 where it was explicitly explained how the bearers participated:

Generally speaking, the incentive for this candidature came from the Ministry of Culture of the Republic of Croatia, Department for Movable and Intangible Heritage, ${ }^{19}$ but with the full support and cooperation from the musicians themselves, folklore groups, local communities and local authorities. At the moment, about a hundred players and singers and about ten traditional instruments craftsmen are the main carriers of the heritage [...]. Many of them have actively participated in the preparation of this file. ${ }^{20}$

The participation of the bearers in the preparation was not explained at all in the first file for the Masterpieces as visible from the 2002 text:

About a hundred players and singers and about ten traditional instruments craftsmen are direct exponents of two-part narrow interval singing heritage. [...] Musical traditions are deeply rooted in the culture of people from Istria and the Croatian Littoral. We can say that music, along with the dialect, is

\footnotetext{
${ }^{19}$ Actually, it was prepared in the Division for Intangible Cultural Goods that was founded in April 2004 within the Ministry under the Department for Movable and Intangible Heritage. From 2013 the Division has been broadened into the Service for Ethnographic Movable and Intangible Cultural Heritage.

${ }^{20}$ The nomination file on Istrian music for the Representative List, 2008, paragraph 5.a.
} 
that cultural dimension which has most defined local identities throughout history. ${ }^{21}$

In 2001, the description of this element as "Istrian Ethnomusical Microcosmos" aimed at the cultural space and more of its different musical expressions rather than at one particular element itself. ${ }^{22}$ There were several different elements encompassed in this text, which were "in the administrative sense" (Ceribašić 2013: 304) separately inscribed into the national Registry in 2007. One of them, "two-part singing and playing in the Istrian scale", was inscribed on UNESCO's Representative list in 2009 as a separate element without any problems. In the nomination for the Representative list, the type of element, the involvement of the communities and the exact bearers were more clearly explained, however, in paragraph 1.d. of the 2009 file, the description of the geographical location remained exactly the same as the above cited text from the 2002 file, without actually making it clearer "where" exactly the element is; still the nomination passed as such although it had not passed in 2002 with the same description in this part of the file. This proves that in addition to the changes made in the text, some new circumstances, which I will explore below, under which the file was proposed for inscription in 2009 influenced UNESCO's decision. A similar thing happened to lacemaking, the second element that Croatia sent for the Masterpieces programme.

Several factors influenced the choice of the second element: political reasons, i.e. the "new administration" (Nikočević 2004: 3), the suggestion of the external experts who were members of a special advisory body at the time (which included Nerina Eckhel from the Ethnographic Museum in Zagreb, a long-time researcher of the selected element of "lacemaking in Croatia"), and making sure that the next element which was to be nominated for inscription would be presented in the best way possible. Thus, higher ranking officials from the Ministry decided to include all relevant external experts, which is why experts from the Department of Ethnology and Cultural Anthropology (Faculty of Humanities and Sciences in Zagreb) who are specialists in the field as well as one other member of the advisory body (from the Institute of Ethnology and Folklore Research) reviewed the file written by Nerina Eckhel. An exhaustive text was drafted in 2004 covering all the necessary criteria: the element was clearly described, its value scientifically supported, the action plan for its safeguarding made and the bearers included in the preparation. However, the element was not inscribed in 2005.

\footnotetext{
${ }^{21}$ The candidature file on Istrian music for the Masterpieces, 2002, paragraph 5.c.

${ }^{22}$ Masterpieces envisioned cultural spaces and unique expressions as two categories of ICH, although it seems that it was more concrete for UNESCO to choose expressions as specific elements of ICH.
} 
When comparing this text to the text about Istrian music, it differs in several points. It is clearer in all of its parts, and it defines precisely what ICH elements it refers to, which proves that the text was more carefully drafted after the experience with the Istrian music candidature. However, the lacemaking file, similarly to the first Croatian file, also defined three cultural spaces and three different styles (and types) of lacemaking, which was probably not acceptable to UNESCO, which aimed at a single clearly defined cultural space or element at the time, although in 2009 lacemaking was inscribed on the Representative List exactly as it was proposed in 2004 for the Masterpieces.

My analysis leads me to conclude that at the time the approach that UNESCO had to tangible cultural heritage influenced the choice, in that the element had to be the most exceptional example, because for the Masterpieces program UNESCO's criteria were also aimed at "proving" that the proposed element is a unique cultural space/expression unlike any other in the surroundings or in the world:

[The candidature file] needs to demonstrate its outstanding value as a masterpiece of the human creative genius [...] in order to prove its outstanding value $[. .$.$] , each candidature file [...] must set out clear [...] arguments dem-$ onstrating: their outstanding value to the community concerned and for the maintenance of cultural diversity in relation to (a) other forms of expression within the same culture/cultural group, (b) the expressions of nearby related cultures and (c) universally. ${ }^{23}$

A comparison of the criteria and the forms for Masterpieces and the World Heritage List shows that they were still quite similar in this respect:

[The element] should represent a masterpiece of human creative genius [...] be an outstanding example of a type of building, architectural or technological ensemble or landscape. ${ }^{24}$

UNESCO's task then was to find a unique and the best version of a type of ICH

[...] the winning entries were chosen for their outstanding value as Masterpieces $[\ldots] .^{25}$

Although the shift from the tangible concept of culture was visible in the criteria for the Masterpieces in that the element cannot be measured by any

\footnotetext{
${ }^{23}$ Guide for the Candidature Files for Masterpieces. 2001, paragraph $23 \mathrm{a}$. and b.

${ }^{24}$ World Heritage List criteria (i) and (iv), http://whc.unesco.org/en/criteria/.

${ }^{25}$ Overview on the Proclamation of Masterpieces, 1-3, http.
} 
external set of criteria ${ }^{26}$ and had to be a living cultural practice, ${ }^{27}$ the initial decisions by the UNESCO had not changed by that time, and the two elements from Croatia could not meet the Masterpieces' criteria at the time.

Therefore, it was not until 2008/2009, when the criteria changed, and with it the nomination form as well as other preconditions that I mentioned earlier, that both elements previously not selected by the UNESCO for the Masterpieces program could now be incorporated into UNESCO's newly established Representative List. ${ }^{28}$ Zebec mentions that "the removal of the term 'masterpiece' is a change in terminology by which [UNESCO] wanted to declaratively highlight that heritage could not be valuable or more valuable, but rather that all [heritage] on UNESCO's lists is equally valuable" (2013: 317). With the new list and criteria, the evidence of being the best possible example of a type of ICH shifted to proving that the ICH element proposed would raise visibility of ICH in general and encourage dialogue (cf. Operational Directives, chapter I.2). This was met not only by lacemaking, but also by Istrian two-part singing, and five other elements out of the 16 proposed for this first cycle of "new" inscriptions. However, for those elements where the texts had already been written previously for their inscription into the Registry, this was the crucial step that preceded the 2008 nomination process that I will turn to next.

\section{THE REGISTRY - FIRST TEXTS}

For the inscription on the Masterpieces list in all three proclamation cycles (2001, 2003 and 2005) it was not mandatory to give evidence that the element is inscribed into the Registry as it has been obligatory since 2008, which was the reason why Istrian music was not inscribed into the Registry prior to its candidature for the 2003 Masterpieces cycle. Only the overall system of protection had to be explained, which was done by listing the activities of museums and associations and the fact that ICH in general is a

\footnotetext{
${ }^{26}$ Guide for the Candidature Files for Masterpieces, paragraph 23.b.ii.: “'masterpiece' [...] understood as a cultural manifestation of exceptional value, defying any formal rules and not measurable by any external yardstick".

${ }^{27}$ Compare the Guide for the Candidature Files for Masterpieces 22.e: "its value as a unique testimony of a living cultural tradition" with the World Heritage criterion (iii): "bear a unique or at least exceptional testimony to a cultural tradition or to a civilization which is living or which has disappeared".

${ }^{28}$ With the 2003 Convention entering into force, the two lists were formed, and the elements that were pronounced as masterpieces in 2001, 2003 and 2005 were inscribed in 2008 into the Representative list. The first cycle of regular inscriptions of ICH elements from around the world took place in 2008 and these elements were inscribed in 2009 (Croatia applied 16 elements out of which seven were inscribed in 2009, two in 2010, two in 2011, and one in 2012 and 2013, and one element on the second, Urgent list in 2010, a total of 14 by the end of 2013).
} 
part of the national Act by which it enjoys special legal status and attention. ${ }^{29}$ It was only later, in 2005, when Croatia met the legal precondition to inscribe ICH elements, and when some countries were already creating their national lists and some of them already inscribed those ICH elements on the Masterpieces list, that the higher ranking officials (including the Minister) in the Ministry considered inscribing ICH that was believed to have the potential for UNESCO's (Masterpieces') list. ${ }^{30}$ The decision to inscribe something on UNESCO's ICH list(s) despite the first unsuccessful inscriptions on the Masterpieces' list, looking at the entire context from this point of view, seems to have been influenced by the experience of Croatia in inscribing tangible heritage on UNESCO's World Heritage List and the effect that these inscriptions had both in the expert and political circles as an "achievement" and a "confirmation" of the value of the inscribed heritage, as well as in the public (although to a significantly smaller extent compared to the effects resulting from later ICH inscriptions).

As a result of the decision to nominate another element for the Masterpieces' list, lacemaking was the first ICH element inscribed into the Registry in 2004. Although the text for UNESCO's Masterpieces program encompassed all three localities and different types of lacemaking in Croatia, they were separated into three elements in accordance with the rules of the standard procedure for inscription into the Registry established by the Ministry: lacemaking from Pag, lacemaking from Lepoglava and lacemaking from Hvar. The standard procedure stipulated that each conservation department ${ }^{31}$ should cover its designated territory (one or more counties) and inscribes the elements separately as they are to be found within the purview of that department, although in the case of an element existing in a broader area, several departments can work together on the inscription.

In addition to those three elements, two other elements were added, paški teg $^{32}$ and pokrivaca ${ }^{33}$ as elements accompanying the Pag lace, both inscribed as oral expressions for the objects worn in the past. Although the 2003 Convention defines ICH in connection to language (article 2, paragraph 2a) as well as to objects (article 2, paragraph 1), it does not imply that the names and the objects should be treated separately as ICH elements in their own right as it had been the case with these two examples, rather, they should be

\footnotetext{
${ }^{29}$ Candidature file on Istrian music, 2002, paragraph 5.d.

${ }^{30}$ Internal report on the activities of the Division for ICH, 2004: 1-3.

${ }^{31}$ As first inscriptions were more "centralized" in that the preparation for inscription of the elements was done in the Ministry's Division for ICH, recent practice is that ethnologists from conservation departments work on the new ones, but it is too soon to evaluate the effects of this shift. Certainly, it would create more close communication with the bearers and communities but it might cause pressure on the experts in the departments.

${ }^{32}$ Paški teg is a type of lacemaking which is assumed to be the historical basis of the Pag lace.

${ }^{33}$ Pokrivaca is a part of the national costume of the area, made partly by using the teg lace.
} 
defined in connection to a specific ICH element, be it practice, knowledge, skill or something similar that is "vivid". Moreover, the Ministry also has the system of incorporating the valuable objects from the past into the Registry by defining them as movable cultural goods, whereas for oral heritage such as local speeches, stories, legends, etc. it has a special system of evaluation as part of $\mathrm{ICH}^{34}$

All this supports the assumption that the first texts were greatly influenced by the previous practice related to tangible heritage: "Protection of ethnographic heritage dealt with objects for a long time [...], and can handle the protection of the intangible with difficulty" (Vitez 2007: 21). It was not until 2007 that a set of rules was clarified by the Committee and the Division for the inscription and writing texts about ICH that reflected on UNESCO's criteria such as endangerment of the element, its significance for, participation of and consent by the community/bearers, continuity, the basic level of documentation, etc. ${ }^{35}$ As there were no rules at the time, all of the five initial texts actually followed the system of description of the candidature file for the Masterpieces program aimed more at the "tangible" aspects of the element: a general description, proving it is a "masterpiece" (why it "stands out" from other aspects of cultural heritage), its historical background and origin. $^{36}$

\section{INTENSIFYING THE WORK ON THE IMPLEMENTATION OF ICH POLICY}

Another activity on ICH policy suggested by the UNESCO ${ }^{37}$ was to form a special body of experts outside the Ministry for the purpose of helping the Ministry of Culture in the decision making process and in preparing texts

\footnotetext{
${ }^{34}$ Expert evaluation of oral heritage is done by the Institute of Croatian Language and Linguistics which takes into consideration local vernaculars, toponymy and stories, but not individual names for objects such as these two examples from Pag. One of the first inscriptions of a vernacular was that from the village of Bednja, which was inscribed as a preparatory (termed preventive) inscription that referred to the local traditional wedding ceremony using the Bednja vernacular. In 2007, it was decided that it is only the local vernacular that can be inscribed as an ICH element in the Registry (Article 9, paragraph 2, point 1 of the 1999 Act), as the wedding ceremony was not a living tradition any longer, only a staged performance.

${ }^{35}$ More about the criteria for inscription in the Registry in Hrovatin (2011).

${ }^{36}$ The resolution documents on lacemaking in Pag, lacemaking in Hvar, lacemaking in Lepoglava, paški teg, Pag and pokrivaca, Pag, 2004.

37 “[...] invited Member States to consider appropriate the establishment of national organs for the protection of the intangible heritage, composed of artists, creative workers and any other actors involved [...] for the proper functioning of the project concerning the Proclamation of Masterpieces [...] not only assume responsibilities in safeguarding, revitalizing and enhancing [...] but also perform specific tasks during the preparation of candidature files [...] advising the national authorities and relevant institutions [...] examining the content of those files before they are submitted to UNESCO [...] how to elaborate a de-
} 
about ICH. In 2002, an Advisory Body was formed, which was renamed as the Committee for Intangible Cultural Heritage in $2004 .{ }^{38}$ In relation to the first texts in 2001 and 2004 for the Masterpieces inscription and in 2004 for lacemaking, the Committee only suggested but did not decide on what was to be inscribed, whereas it has played an important role since 2006 during a more intensive period of enlisting, when many dilemmas had to be resolved and many decisions made.

By 2007, the Ministry issued several official calls for proposals for what was termed "spiritual", living or traditional heritage, and various proposals were collected from various institutions, most of them from the Institute of Ethnology and Folklore Research, many museums and the Ministry itself (mainly its conservation departments). It is those ICH elements that are more or less the ones appearing on the lists today, with the exception of several that came directly from the local communities (e.g. most dealing with food preparation and several musical expressions, the dance Kolo na $d v a$ štuka, the carnival custom from Novi Vinodolski, the Easter custom of shooting from old pistols in Kostel, the craft of making the batana boat in Rovinj, and others).

In 2006, the Masterpieces' form was still adhered to when writing the text about the Festivity of Saint Blaise, ${ }^{39}$ which was to be one of the next ICH elements to be inscribed in the Registry starting a new cycle of inscriptions. However, this is the very first time since the texts about ICH elements were written in the Ministry that a text contained all the information that new texts nowadays also contain, which, in addition to the description of the element, its history and expert evaluation of its significance, also includes the emotional charge that the element has for its bearers, i.e. the bearers' view of the element:

For more than a millennium, Dubrovnik has worshiped its Protector, who in return gives it his love. It gives a special seal to the City, the mentioned saint's omnipresence. He is the first citizen of Dubrovnik (his holiday is still celebrated as the Day of the City today), its heavenly protector, a power in troubled times, a pride through history. ${ }^{40}$

tailed action plan [...] monitor the plan's implementation [...]" (Annex II. of the Guide for the Candidature Files for Masterpieces).

${ }^{38}$ The members of the Committee were changed several times until 2012, when it was decided that the Committee should consist of seven experts from different research areas and institutions (cf. Zebec 2013: 318).

${ }^{39}$ The Festivity of Saint Blaise is a millennium-old traditional several-day-long social and religious event in Dubrovnik, in southern Croatia, celebrating Saint Blaise (lat. Blasius).

${ }^{40}$ The proposition for the inscription of the festivity from the Conservation Department in Dubrovnik (2006: 2) 
The current status of the element and the "dangers" it faces were also clearly described, which significantly shifted the way of thinking about the whole process of listing in the Division in Zagreb. ${ }^{41}$ Initially, there were discussions between the Division and the Committee as to what the text about the ICH element should look like, and the only option at the time was to base it on the texts for tangible elements, taking into account the opinion of the members of the Committee who believed that the data in the texts for inscription should not include the current "status" of the element, because it would mean that the inscription tends to keep the element as it is, "petrified" in time and space. This point had been an unresolved dilemma among experts for a long time, and one of the reasons that only five elements were inscribed from the enactment of the 1999 Act until 2007. Defining the aspects of the element that need to be "preserved" or in what way the element is "endangered" was another dilemma for the experts, who knew it would be a sort of "intrusion" into the element itself. Finally, it was agreed that the text should cover both the expert point of view with an exact "placement" and the description of the element (where (exact location), when (what time of the year or life span), how (e.g. how the custom is performed, what are the phases of making an object in a traditional craft, etc.), why (for what social or other purpose)), the current state of the element and overall suggestions of what should be preserved for the future, i.e. why the element is chosen for inscription:

The Festivity of Saint Blaise, the patron saint of Dubrovnik, represents an exceptional phenomenon of intangible cultural heritage within the cultural space of the town and its surroundings which has, in a continuous historical duration from the 10th century, kept its traditional and recognizable forms and excellence of expressions. ${ }^{42}$

As well as the bearers' attitudes who insisted almost in all cases of inscriptions that their point of view should be clearly mentioned together with the emotional aspect they bring into it:

There are no written rules by which one could become a moreškant. ${ }^{43}$ Special care is given to the quality of the performance and the costumes [...] Korčulans who were moreškants and bulas ${ }^{44}$ enjoyed special privileges in the

${ }^{41}$ The Ministry's Division hired additional experts in 2006, which also proved important for a better organization and the quality of work and was also one of the factors contributing to the increase in the number of inscriptions of ICH elements on the lists.

${ }^{42}$ The resolution document on the Festivity of Saint Blaise, Dubrovnik (2007: 1).

${ }^{43}$ Moreškant is a male person that performs moreška, the sword dance/drama from Korčula.

${ }^{44} \mathrm{Bula}$ is a female person that performs a part of moreška, the sword dance/drama from Korčula. 
community $[\ldots]$ and a long time after a performance is over the feelings $[\ldots]$ and anecdotes $[\ldots]$ are being retold $[\ldots] .^{45}$

Nevertheless, there was another issue that the Committee and the Division could not address without criticism: the arbitrary extraction of elements for inscription from the broader context of culture. This was also the reason why it took a long time to decide what an all-encompassing text about an ICH element should look like. It was obvious that the text would not be able to cover all the aspects of an element and that there are many ways in which even a single element can be interpreted and categorized, because "it is difficult to deal with [the elements'] complexity" (Ceribašić 2013: 306). A special text with an accompanying form concerning an ICH element was finally agreed upon in 2007, which also provided the necessary connection between administration, experts and bearers, who all had to be in close contact with each other to produce such a text. This was the first critical step in creating a list of ICH elements in Croatia, which became the formula leading to the satisfaction of all three sides as well as to an intensification of inscriptions into the Registry and the first inscriptions on UNESCO's lists. The fact that from 2007 until the end of 2013 as many as 137 ICH elements from Croatia were inscribed into the Registry and 14 of them on UNESCO's lists of ICH supports this claim. As it is both administration and external experts that give information to the bearers about the possibilities of safeguarding, this connection today generates a certain number of programs that include ICH (e.g. its promotion, documenting, etc.), that have been received annually as proposals since 2008, some 300 of which have been supported by the Ministry of Culture as of 2014. The possibility of financial support both from the Ministry and other institutions and sources (e.g. local authorities) was one of the motivations behind the inscriptions into the Registry (although not as strong as some other types of motivation).

The inscription on UNESCO's lists, however, did not only depend on this new type of text and cooperation, but also on additional activities of the Ministry and experts in various situations. For example, the experts from the Committee, the Department for UNESCO and the Division for ICH attended international meetings and communicated with UNESCO representatives. The membership of Croatia in the UNESCO ICH Committee (2008-2012) and the Advisory Body were essential in getting the support to inscribe the elements. The Ministry also organized an international seminar for ICH experts in 2009, which proved to be a good opportunity to present Croatian ICH to the representatives of UNESCO prior to the inscription of the nominations

\footnotetext{
${ }^{45}$ The resolution document on Moreška (2007: 2). The subjective view of the bearers was not part of the text that was first received from the external experts; it was added after a discussion with the bearers that I conducted as a Ministry official.
} 
and explain the intention to inscribe the elements into UNESCO's lists. The rationale behind the decision of higher-ranking officials from the Ministry to send as many as 16 nominations to UNESCO was to represent all the major geographical areas in Croatia, and I communicated this idea to the UNESCO Division for ICH in Paris (that officially receives the nominations), where I brought all the nomination files in 2008. This made me an active participant (a position I also had many times after that) in ensuring that at least some of UNESCO's representatives understood why Croatia selected the elements it did and why these elements meet UNESCO's criteria for inscription. The context of the processes taking place between institutions is a complex one, and certain goals are not achieved just through official correspondence. Today, there are a limited number of nominations that can be sent to UNESCO by the countries that already have their elements inscribed, so, it turned out to be a "good" decision of the higher ranking officials to send more nominations in the beginning stages of the making of the list. ${ }^{46}$

\section{DEVELOPING ICH POLICY}

The new template developed in the Division for ICH was used in the text about the Festivity of Saint Blaise as well as bećarac, ${ }^{47}$ Sinjska alka ${ }^{48}$ and moreška. Influenced by UNESCO's new approach, the main criteria for choosing what to inscribe in the Registry, together with the importance that the element has for local identity, became the endangerment of the element (Guide for the Candidature Files for Masterpieces 3f) and participation of the bearers, reflected in expert reviews:

Two basic motives for the inscription in the Registry [...] are the importance of a tradition for the cultural identity of the community [...] and the necessity of its protection [...] compared to other genres [...] of traditional music - it cannot be said that its viability is in danger and that it needs protection [...].

${ }^{46}$ The Ministry's Department (today: Service) for UNESCO, that had also been actively involved in the processes of ICH enlisting both in the Registry and especially on UNESCO's lists since the very beginnings from 2000 until today, confirmed in 2008 that there were no limitations on the number of the nominations per country for 2009 inscriptions. As UNESCO could not administratively have handled all the numerous nominations received during the first years of the new lists, today, in instructions for each nomination form, it is explicitly stated that the country sending several nominations to one of UNESCO's three lists has to rank them according to its view of their priority (see forms' page: http://www.unesco. org/culture/ich/index.php?lg=en\&pg=00184).

${ }^{47}$ Bećarac is a musical and oral literary genre composed of decasyllabic verses through which inhabitants of Eastern Croatia express themselves and their identity.

${ }^{48}$ Sinjska alka stands for a contest between several carefully chosen contestants who ride horses at full gallop aiming their lances at a ring. It is a three-century long tradition and expression of cultural identity of the town of Sinj (in southern Croatia) and its surrounding area. 
The proposers are bearers themselves [...] which complies with UNESCO's propositions that the bearers of the tradition should be the main subjects of the protection project. ${ }^{49}$

The review actually stated that Bećarac does not have to be inscribed as it is not endangered, but the decision by the higher-ranking officials (one of whom felt it as his own identity marker because he came from the area where this tradition is upheld), the fact that it is a significant part of the culture of that area and the fact that the set "official" criteria were met, led to its inscription.

As the number of proposals for inscriptions increased since the initial inscriptions on UNESCO's Representative list in 2009, the texts about ICH elements had to be prepared in a very short time due to various pressures from inside and outside the Ministry, which led to the fact that the experts from the Division could not contact all the bearers. In most cases, the experts from the Committee and from various professional and scholarly institutions were invaluable in facilitating communication between the Ministry's officials and the bearers. They would and still do explain the purpose $(s)^{50}$ of the inscription to the bearers and collect the bearers' attitudes towards the element (or they might already know it). This was also in part due to the fact that in many cases the experts decided to inscribe elements that were sufficiently documented, and the many elements selected for the Registry corresponds to those that the experts from the Committee (over 20 different experts were involved in the work from 2002 until today) and other external experts conducted research on (in addition to the ones already mentioned, this includes ojkanje singing, the spring custom of kraljice from Gorjani, many vernaculars, dances from the island of Krk, etc.). This coordination was also reflected in naming the elements: e.g. moreška retained the suggested ${ }^{51}$ scholarly name "sword play" which the bearers accepted, while Sinjska Alka kept its bearers' categorization as a "chivalric game", which was later also kept for UNESCO's list. Usually, the bearers want to keep their perception of the element in the official version inscribed on the list, because it is more easily recognized by them and the general public. I believe that this also

\footnotetext{
${ }^{49}$ Both citations from the Expert Review on Bećarac 1 (2006: 1, 2).

${ }^{50}$ The "official" goals of the inscription (such as raising visibility of ICH, creating intercultural and international dialogue, etc.) and the unofficial goals (more possibilities of financing various activities of safeguarding) are both explained in the 2003 Convention and on UNESCO's website (http://www.unesco. org/culture/ich).

51 "The name for moreška is, however, inconsistent in the proposal - the name Korčulans use for it is based on the public opinion about the past and tourist trends, which refer to medieval games as 'chivalric', although in the sources they cite it is referred to as a sword battle game, or sword battle dance... the Korčulans did not take into consideration the [scholarly] texts in their proposal, although [they were familiar with them]" (The Expert Review on Moreška 1 2006: 2).
} 
reflects the significance of the listing for the communities and their symbolic placement on the lists.

For most elements a review was commissioned from an expert who has done research on the element or the type of ICH to which the element belongs (music, dance, play, custom, craft, etc.). These reviews and suggestions on how to improve the text have been taken into consideration in writing the final versions of the official document on an ICH element:

As it is one of the key symbols of the traditional Slavonian musical practice, I consider it appropriate to inscribe bećarac [...] I would like to warn about some data which is unacceptable from an expert point of view. ${ }^{52}$

In some cases there were almost no relevant ethnographic sources that would provide enough data for some elements to be inscribed, and those texts were written by the experts in the Division for ICH on the basis of various sources (direct contact with the bearers, historic sources, professional and scholarly work from other disciplines, the Internet). Some of the suggestions for inscription into the Registry came from local communities and some from various political groups for a variety of reasons. Until recently, politicians actually tried to speed up the process of inscription of elements which had already been valorised by experts, rather than trying to select what to inscribe. Pressures to speed up the process also had a negative effect on the quality of the texts about ICH elements, some of which were not written to the standard suggested by the experts from the Committee and the Division. For example, information on the historical background or changes of the element, on similar examples that are still practiced elsewhere, etc. would be missing. Another problem that arose as the texts were written was the non-existence of recent documentation and research from the field which would provide more recent data and insight into the current state of some elements. When I was asked by some of the bearers whether it was possible to inscribe their element despite the lack of data, I would communicate it to the Committee and to my superiors, who would at first usually not be sure whether to inscribe it or not (suggestions are either to wait for future research or put the element into wider categories of ICH, etc.). However, the bearers would like the element to be inscribed as soon as possible, which usually results in the text missing some of the information about the element, and the final text that I would write together with the bearers in such a case would reference the lack of reliable data:

\footnotetext{
${ }^{52}$ From the Expert Review on Bećarac 2 (2006: 1).
} 
According to the available data gathered until today, it can be presumed that this jewellery is specific only to this area. ${ }^{53}$

From my position as an administrative expert serving the public, I have taken the position of an "advocate" of those elements and communities, sometimes even contacting them first, so my efforts resulted in the inscription of those particular elements (e.g. traditional fishing in Lonjsko polje, the traditional skill of decorating Easter eggs, the artistry of making traditional Christmas decoration kinč and luster, and several others).

Pressures from outside and inside the Ministry were present since the beginning of listing, and came from various levels, from the highest ranking state officials through experts to bearers and officials on the local administrative level. Today the pressures decreased and it was decided that some of the elements would have to be redefined in various ways: some would have to be included into broader categories as they appear too particular for the Registry, and some would have to be named differently (e.g. some of the crafts are to be renamed from "traditional crafts" into "a traditional way/skill of making a certain object" etc.). Although lacking scholarly data, the texts that give basic information about the elements which have still not been researched in depth could be used as the basis for future research (one of the safeguarding measures), providing a valuable starting point.

From the reaction of the communities and the public, it seems that the inscriptions, especially on UNESCO's lists, have changed the attitude towards some of the elements. The media largely uncritically reflected on the inscriptions as a positive thing for the inscribed element, and some of the comments of the public available online as a response to such media coverage were also positive. However, most of the positive effects of inscriptions were communicated to the Ministry via direct communication with the bearers, where they expressed their satisfaction about the inscription, mentioning the fact that it changed the public attitude towards their heritage, especially if it had been negative before, that they feel less ashamed when presenting it, as well as that they are finding ways to transmit the knowledge to younger generations, trying to raise funds for their activities, and so on, which, in some examples (e.g. ojkanje), had not been the case before. For ojkanje, what was communicated to the Ministry was also said to the public: "The goal of our festival is to keep and preserve the old way of singing [...] ojkanje is not uncontrolled shouting, nor uncultivated singing" (Talijaš 2012: 1), which had been the perception of the public before the inscription.

Based on my communication with the communities in Croatia they already know how to "use" their heritage, so the influence the listing had is only one

\footnotetext{
${ }^{53}$ From the Resolution document on making koladre jewellery (2012: 1).
} 
of many influences already shaping the attitudes and culture in Croatia. From several dozen of such contacts with the representatives of communities and bearers, I conclude that besides the need for the protection of their rights, most communities want the inscription on the ICH list(s) to confirm that their heritage is valuable, based on expert evidence and recognition by the state (the Ministry) or an international body (UNESCO). This was the case particularly after the first inscriptions on UNESCO's Representative list, when many people would call and almost word for word say that they want their heritage to be inscribed at least on the Registry if not on UNESCO's list. Many would propose a tradition that is different from the ones already listed or a tradition that could be inscribed separately, although they have another tradition that was or could be inscribed together with several other communities. From my insight into these proposals, nearly all of them, besides the already mentioned ones, had a very important underlying motivation: to become visible within the context of the listing i.e. within the context of the cultural scene on the "national" (the Registry) and/or the "world" (UNESCO's lists) level. From the follow-ups regarding the elements given to the Division, I came to the conclusion that the inscriptions had important social and public implications, some of which either initiated or just encouraged open expression of identity, the need to become more recognizable within the country and abroad, the ambition to "use" the heritage for other purposes such as tourism, politics, etc. This complex "selection" of the ICH elements that would serve the desire of the community to represent itself deserves a separate analysis that would confirm all the mechanisms governing it.

The categorization of the ICT in the legislation or in the bearer's interpretation did not always correspond to the expert opinion. Negotiating between the wishes of all three levels, the administrative, the expert and the community level, was part of many inscriptions. One of the first such cases was the Legend about Picoks, ${ }^{54}$ which was an identity marker for the local community, but about which the Ministry's higher-ranking officials, the experts from the Division for ICH and the Committee could not reach a consensus and decide whether to inscribe it at all, and, if so, under which category.

It was inscribed as a draft proposal (termed "preventive") in 2003 with the deadline of 3 years under the name "Traditional oral story 'Legend about Picoks"' and again in 2006 as the "Legend about Picoks' - Slovenian ${ }^{55}$ Staged Performance". The text started with mentioning the tangible heritage of the area connected with the performance, which again confirms how deeply

\footnotetext{
${ }^{54}$ The Legend about Picoks is the name of an ICH element from the town of Đurđevac in northwestern Croatia. It is the oral story about an event from the history of the town, on the basis of which a staged performance was written and enacted each year in memory of the event.

55 "Slovenian", because during the first attempt to inscribe the element there was a dispute about the authorship of the staged performance, one version of which was written by a Slovenian artist.
} 
rooted the concept of tangibility of culture was in the administrative apparatus at the time:

The fortress, which is the place where this oral expression is staged and one of the oldest objects of this type in the area [...] is a protected cultural good. ${ }^{56}$

In 2006 the Division for ICH invited reviews, which categorized it completely differently:

On the basis of these facts, it is clear that the cultural, entertaining, sports and tourist manifestation called Legend about Picoks held traditionally [...] in Đurđevac is a self-standing and valuable cultural phenomenon in the diversity of Croatian cultural heritage, and I suggest [...] with full confidence that it be inscribed on the List $[\ldots] .^{57}$

Obviously there is a dilemma on what to protect: the oral expression or its staged performance. According to the [preventive] Resolution the oral expression is protected, but it is unjustly connected to the author's work [...] from 1977 called "staged folk game" (unjustly as there are several author versions [...]). The text should either be more general or based on an informant's version of the story. ${ }^{58}$

My role in this particular case was to negotiate an agreement with the experts on how to inscribe the element so that it would "fit" the already established definitions and criteria for ICH listing, and we agreed that the best solution was to put it under the category of oral expression, which corresponds to Article 9, paragraph 2, point 1 of the 1999 Act, so in the end this element was inscribed in 2007 as: "Legend about Picoks - a traditional oral story". In the comment by Zorica Vitez it is clear that some of the members of the Committee had doubts about protecting and categorizing it as ICH because it "does not fit into the scope of protection of intangible cultural goods that are based on the activities and concepts of UNESCO" (Vitez 2007: 22). My position was again very fragile as I had to follow the orders of the higher-ranking officials in the Ministry to inscribe the element, so, to resolve the issue of the inscription I had long conversations with several of the members of the Committee with the aim of mitigating the decision of the Ministry to inscribe the element and their determination not to inscribe it. The element would have been inscribed whether or not the experts gave their positive opinion, but if agreement was reached with at least some of the external experts, ten-

\footnotetext{
${ }^{56}$ It was influenced by the tangibility surrounding the element rather than its' own worth as an oral tradition. Resolution documents on preventive protection of the Legend of Picoks (2003 and 2006: 1).

${ }^{57}$ Expert review on Picoks Legend 2 (2006: 5).

${ }^{58}$ Expert review on the Picoks Legend 1 (2006: 2).
} 
sion would be reduced and further cooperation between the Ministry and the external experts continued.

The experts from the Ministry and the Committee still have not reached the point where such examples of traditional heritage that do not fit into the neatly set categories and definitions of ICH would be inscribed in the form they exist today, and this is usually decided upon on a case-by-case basis, forcing it into one of the existing "niches". It would take some time to reach the expert attitude toward it and change the strict following of the already defined categories. Some of the proposals for inscription are still being debated and await the decision of whether to inscribe them or not, as communities do consider them "living" and part of their identity and history (e.g. the custom Zapovijed pod Lipom). For now, there is agreement between the Division and the Committee that the so-called manifestations and/or festivals are not within the broader definition of $\mathrm{ICH}$, which resulted in the more general decision that they should not be inscribed (e.g. Vinkovačke jeseni, Đakovački vezovi, etc.).

\section{CONCLUSION}

The first inscriptions of ICH elements in the Registry were influenced by the preparation of proposals for the UNESCO program of Proclamation of Masterpieces of Oral and Intangible Heritage of Humanity, as well as the idea of world lists of ICH later established by the 2003 Convention. This influence is visible in the texts that describe the initial ICH elements, and they testify to the changes in the approach to treating ICH as a separate type of heritage. The emphasis was at first mainly on historical data and a more general description of the element, explaining its value and emphasizing its national and international placement in order to prove its "universal" value. For ICH it proved to be a difficult task to define the uniqueness of each element, as there are many various practices in the world.

The experts were the ones who made the first "rough" selection of ICH elements that should be inscribed in the lists. In Croatia, experts from the Committee, both with their positive and critical attitude, proved to be one of the several main contributors to the development of Croatian ICH policy established by the Ministry of Culture. When a new approach developed both in UNESCO and the Ministry on the basis of the first inscribed elements, new possibilities opened for the evaluation of ICH elements. From the initial attitude of the scholars and experts about the most "valuable" examples of ICH that "deserved" inscription, the emphasis of the criteria shifted to the "emotional" charge of each element and the willingness of the bearers and various other influences coming from different sides to inscribe it on the list. 
Having in mind the changing aspects of cultural expressions, it was agreed among the experts in Croatia who work on ICH listing that the terminology and categorization should remain open to define each element separately. Writing the nominations had three major layers: the first layer was the expert text which proved to be important to describe the ICH element and its changes and significance through time; the second layer was proving that the bearers participated in the preparation of the file, suggested further measures and explained what the element signifies to them; and the third layer was convincing UNESCO why the element should be inscribed. It was not important to describe "how" but "why", which was, for a long time, one of the major obstacles for writing the text about the ICH element.

In many communities the inscriptions triggered the need to select and propose a cultural practice they consider representative of themselves, their history and place of living, rethink all the elements they have and revalorize them, which in turn influenced their attitude towards their heritage. In this sense, political influence on inscriptions was only one part of the broader context of the processes that have been happening in the realm of "culture". On the other hand, additional effort to convince the decision makers from the Ministry to inscribe an element, and not only articulate it in the text of the proposal, included various types of communication with experts outside or inside the Ministry, higher-ranking officials or other influential persons/ groups that contributed to the justification of inscription. This was also true on the other level, that of the Ministry sending nomination files to UNESCO, which, in addition to a special type of text, also included different kinds of communication with the experts and officials in the UNESCO and its bodies. Without those different layers of persuasion, there might have been more difficulties in achieving so many inscriptions both on the national and the international level.

Creating the lists and choosing some elements over others is arbitrary and cannot be "objective" no matter how one tries to elaborate it, which this analysis also clearly illustrates. I believe that all countries have to face certain issues resulting from the attempt to make ICH lists, because ICH is full of emotions, but also something that, in UNESCO's terms, "individuals, groups and communities" use for various purposes depending on the context and their placement in it. Some analyses have already shown that heritage can be used "politically" in various ways, not only by "high" politics but also by those who claim it as theirs. From my point of view as an insider, I think that UNESCO's ICH policy raised some complex issues in the cultural domain, issues which may not have been so obvious before, but which became more clearly visible during the process of inscription.

The pressures that I had to take as an administrator, an expert and a person were manifold and came from various sides: the experts, my superiors, 
the bearers, the communities and myself. Of course, after the initial phase, I found a way to tackle the issues as they came, depending on the situation and the "stakeholders", which always generated new experience.

\section{LITERATURE AND SOURCES}

Act on the Protection and Preservation of Cultural Goods. 1999. Available at: http://www. unesco.org/culture/natlaws/media/pdf/croatia/croatia_act_protectionclturalgoods_ engtof.pdf and in Croatian http://narodne-novine.nn.hr/clanci/sluzbeni/271022.html (accessed 15 December 2013).

Candidature file on Istrian music "Istrian Ethnomusical Microcosmos" for the Proclamation of Masterpieces. 2002. Archive of the Ministry of Culture, Croatia.

Candidature file "Lacemaking in Croatia" for the Proclamation of Masterpieces. 2004. Archive of the Ministry of Culture, Croatia.

Ceribašić, Naila. 2013. "Novi val promicanja nacionalne baštine. UNESCO-ova Konvencija o očuvanju nematerijalne kulturne baštine i njezina implementacija". In Proizvodnja baštine. Kritičke studije o nematerijalnoj kuturi Marijana Hameršak, Iva Pleše and Ana-Marija Vukušić, eds. Zagreb: Institut za etnologiju i folkloristiku.

Convention for the Safeguarding of Intangible Cultural Heritage. 2003. UNESCO. Available at: http://www.unesco.org/culture/ich/index.php?pg=00006 (accessed 15 December 2013).

Decisions Adopted by the Executive Board at its 155th Session. 1998. UNESCO. Available at: http://unesdoc.unesco.org/images/0011/001142/114238e.pdf (accessed 15 December 2013).

Decision on protected geographical indication of Slavonski kulen. Available at: http://www. mps.hr/default.aspx?id=9450 (accessed 10 August 2013).

Expert review on Bećarac 1. 2006. Archive of the Ministry of Culture, Croatia.

Expert review on Bećarac 2. 2006. Archive of the Ministry of Culture, Croatia.

Expert review on the Istrian Ethnomusical Microcosmos. 2001. Archive of the Ministry of Culture, Croatia.

Expert review on Moreška 1. 2006. Archive of the Ministry of Culture, Croatia.

Expert review on Picoks Legend 1. 2006. Archive of the Ministry of Culture, Croatia.

Expert review on Picoks Legend 2. 2006. Archive of the Ministry of Culture, Croatia.

Guide for the Candidature Files for Masterpieces. 2001 and 2003. UNESCO. Available at: a) http://unesdoc.unesco.org/images/0012/001246/124628eo.pdf and b) http://portal. unesco.org/culture/es/file_download.php/abe155dc9d7d01c1f89adbd39a5fb825AnnexeVI-Eng.pdf (accessed 15 December 2013).

Hameršak, Marijana and Iva Pleše. 2013. "Uvod u proizvodnju baštine”. In Proizvodnja baštine. Kritičke studije o nematerijalnoj kuturi. Marijana Hameršak, Iva Pleše and Ana-Marija Vukušić, eds. Zagreb: Institut za etnologiju i folkloristiku.

Hrovatin, Mirela. 2011. "The Safeguarding and Listing of Intangible Cultural Goods in Croatia / Registriranje i očuvanje nematerijalnih kulturnih dobara u Hrvatskoj". Collection of paper from international conference Craftattract - traditional crafts-new attractions for cultural tourism. Museums of Hrvatsko zagorje. Available at: http://www.craftattract.com/ pdf/Zbornik-Craftattract.pdf (accessed 15 January 2013). 
Internal reports on the activities of the Division for ICH. 1999-2013. Archive of the Ministry of Culture, Croatia.

Kirshenblatt-Gimblett, Barbara. 2013. "Svjetska baština i kulturna ekonomija”. In Proizvodnja baštine. Kritičke studije o nematerijalnoj kuturi. Marijana Hameršak, Iva Pleše and AnaMarija Vukušić, eds. Zagreb: Institut za etnologiju i folkloristiku.

Nikočević, Lidija. 2004. "The Intangibility of Multiculturalism”. Available at: http://icme.icom. museum/fileadmin/user_upload/pdf/2004/nikocevic.pdf (accessed 15 December 2013).

Nikočević, Lidija. 2012. "Culture or Heritage? The Problem of Intangibility?" Etnološka tribina 35/42: 57-112

Nomination file on Istrian music "Two-part Singing and Playing in the Istrian Scale" for the inscription on the UNESCO's Representative List of Intangible Cultural Heritage. 2008. Archive of the Ministry of Culture, Croatia.

Nomination file on "Lacemaking in Croatia" for the inscription on the UNESCO's Representative List of Intangible Cultural Heritage. 2008. Archive of the Ministry Official correspondence between the Ministry and UNESCO. 1999-2013. Archive of the Ministry of Culture, Croatia.

Operational Directives for the Implementation of the 2003 Convention. Available at: http:// www.unesco.org/culture/ich/en/directives (accessed 15 December 2013).

Overview on the Proclamation of Masterpieces of the Oral and Intangible Heritage of Humanity - UNESCO. Available at: a) http://www.unesco.org/culture/ich/index.php?pg=00103 and b) http://www.unesco.org/bpi/intangible_heritage/backgrounde.htm (both accessed 15 December 2013).

Proposal for the inscription of festivity of Saint Blaise, Dubrovnik. 2006. Archive of the Ministry of Culture, Croatia.

Report on UNESCO and ACCU Expert Meeting on Community Involvement in Safeguarding Intangible Cultural Heritage: Towards the Implementation of the 2003 Convention. Available at: http://www.unesco.org/culture/ich/doc/src/00034-EN.pdf (accessed 30 December 2008).

Resolution documents on preventive protection of the Legend of the Picoks. 2003 and 2006. Archive of the Ministry of Culture, Croatia.

Resolution document on dance/play Moreška, Korčula. 2007. Archive of the Ministry of Culture, Croatia.

Resolution document on Festivity of Saint Blaise, Dubrovnik. 2007. Archive of the Ministry of Culture, Croatia.

Resolution document on making of jewelry koladre, Jastrebarsko. 2007. Archive of the Ministry of Culture, Croatia.

Resolution document on music and oral expression Bećarac, Eastern Croatia. 2007. Archive of the Ministry of Culture, Croatia.

Resolution document on lacemaking in Pag. 2004. Archive of the Ministry of Culture, Croatia.

Resolution document on lacemaking in Hvar. 2004. Archive of the Ministry of Culture, Croatia.

Resolution document on lacemaking in Lepoglava. 2004. Archive of the Ministry of Culture, Croatia.

Resolution document on paški teg, Pag. 2004. Archive of the Ministry of Culture, Croatia.

Resolution document on pokrivaca, Pag. 2004. Archive of the Ministry of Culture, Croatia.

Resolution document on traditional contest Sinjska alka, Sinj. 2007. Archive of the Ministry of Culture, Croatia. 
Recommendation on the Safeguarding of Traditional Culture and Folklore. 1989. Available at: http://portal.unesco.org/en/ev.php-URL_ID=13141\&URL_DO=DO_TOPIC\&URL_SECTION=201.html (accessed 15 December 2013).

Representative List of Intangible Cultural Heritage of Humanity (Croatian nomination forms). Available at: http://www.unesco.org/culture/ich/index.php?lg=en\&pg=00559 (accessed 15 December 2013).

Study for Protection of Korčulan Moreška. 2001. Town of Korčula. Archive of the Ministry of Culture, Croatia.

Talijaš, Ante. 2012. "Ojkanje is not Just Shouting, but Real Multipart Singing / Ojkanje nije puko deranje, već pravo višeglasje!" Available at: http://sibenskiportal.hr/2012/08/13/ foto-ojkanje-nije-puko-deranje-vec-pravo-viseglasje (accessed 20 August 2012).

Vitez, Zorica. 2007. "The Legend of the Picoks [Legenda o Picokima] in the Light of Global and National (Cultural) Policy". Narodna umjetnost 44/2: 11-25.

UNESCO reflection on issues behind the making of the 2003 Convention. Available at: http:// www.unesco.org/culture/ich/index.php?lg=en\&pg=00308 (accessed 5 September 2013).

World Heritage List: criteria and form. Available at: http://whc.unesco.org/en/criteria/ (accessed 15 December 2013).

Zebec, Tvrtko. 2013. "Etnolog u svijetu baštine. Hrvatska nematerijalna kultura u dvadeset i prvom stoljeću". In Proizvodnja baštine. Kritičke studije o nematerijalnoj kuturi. Marijana Hameršak, Iva Pleše and Ana-Marija Vukušić, eds. Zagreb: Institut za etnologiju i folkloristiku.

\title{
PISANJE "NEMATERIJALNOG" TEKSTA: IZMEĐU POLITIKE, ZNANOSTI I NOSITELJA
}

\author{
SAŽETAK
}

U tekstu se daje pregled prvih slučajeva upisa nematerijalne kulturne baštine u Registar kulturnih dobara Republike Hrvatske te se pokazuje da je UNESCO imao veliki utjecaj na opis i valorizaciju elemenata nematerijalne kulturne baštine u Hrvatskoj. U radu se upućuje i na neke od problema s kojima su se suočavali i koje su pokušali riješiti stručnjaci koji su radili na upisu nematerijalne kulturne baštine u Registar kulturnih dobara, a autorica se povremeno osvrće i na politiku nematerijalne kulturne baštine uopće. Osim toga, autorica piše i o vlastitoj poziciji stručnjakinje u državnom tijelu, koja nastoji pomiriti znanstvena očekivanja, političke zahtjeve i stavove nositelja prema nematerijalnoj kulturnoj baštini. Prvi pokušaji sastavljanja tekstova o nematerijalnim kulturnim dobrima izabranim za upis u Registar kao i na UNESCO-ovu listu nematerijalne kulturne baštine analiziraju se na temelju dostupnih arhivskih dokumenata i literature. U analiziranim se tekstovima jasno vidi pomak od koncepta materijalnog aspekta kulturne baštine prema nematerijalnosti kulturnih praksi. Zaključak upućuje na postojanje različitih utjecaja na proces upisivanja i izbora dobara za upis u Registar, što svjedoči o složenosti kulture i implikacijama koje ona nosi.

Ključne riječi: nematerijalna kulturna baština, UNESCO, Registar kulturnih dobara Republike Hrvatske 